\title{
SPOLECZNE I KULTUROWE UWARUNKOWANIA I OGRANICZENIA PROCESU POKOJOWEGO W IRLANDII PÓŁNOCNEJ
}

$\mathrm{M}$ ija 13 lat od podpisania pokojowego porozumienia w Ulsterze - 10 kwietnia 1998 r. po długich rozmowach rządy brytyjski i irlandzki oraz największe północnoirlandzkie partie podpisały Good Friday Agreement (Porozumienie Wielkopiątkowe). Jakie są efekty rozpoczętego kilkanaście lat temu procesu pokojowego? W jakim kierunku on podąża?

Tak postawione pytania wymagają sprecyzowania. Po pierwsze: czy zmieniły się relacje pomiędzy republikanami/nacjonalistami a lojalistami/unionistami? Po drugie: czy w obrębie samych społeczności zaszły zmiany, które mogłyby wspierać i oddolnie wspomagać proces pokojowy? Po trzecie: czemu ten proces ma służyć? Czy końcowym efektem ma być wspólnota, naród północnoirlandzki? czy, co bardziej prawdopodobne, dwie stosunkowo - kulturowo i społecznie - odrębne zbiorowości koegzystujące $w$ ramach jednej struktury państwowo-administracyjnej?

Wydaje się, że polityka nowego rządu wskazuje raczej na to drugie rozwiązanie. Jest to rozsądna strategia zmierzająca, przynajmniej na początkowym etapie, do zmniejszenia dyskryminacji mniejszości katolickiej oraz do stworzenia podstaw - ekonomicznych i politycznych - szeroko rozumianej polityki społecznej prowadzącej do wyrównania szans członków obu społeczności. Z drugiej strony gtówny program rządowy, rozpoczęty w 2001 r., a kontynuowany w latach 2003 i 2005, nosi nazwę $A$ Shared Future, symbolicznie podkreślając potrzebę zmian postaw obu społeczności względem siebie, od wrogich i nieufnych, do bardziej otwartych, uwzględniających konieczność współżycia w obrębie jednego państwa.
Dr Ewa SZCZECIŃSKA-MUSIELAK jest adiunktem w Katedrze Socjologii Szkoły Głównej Gospodarstwa Wiejskiego w Warszawie. ewa_szczecinska@wp.pl 
Dwaj główni aktorzy to mniejszość katolicka, w obrębie której można wyróżnić nacjonalistów (zwolenników przyłączenia Ulsteru do Republiki Irlandii) oraz republikanów (zwolennicy zjednoczenia wyspy, jednocześnie zwolennicy walki zbrojnej). Nie wszyscy katolicy to republikanie czy nacjonaliści. Z drugiej strony są protestanci, wśród których wyróżnia się unionistów (zwolenników zachowania unii z Wielką Brytanią, przeciwników walki zbrojnej) oraz lojalistów (zwolenników zarówno zachowania unii, jak i walki zbrojnej). Analogicznie, nie wszyscy protestanci są lojalistami lub unionistami. W obu społecznościach - katolickiej i protestanckiej - członkami bojówek i zwolennikami „walki” są przedstawiciele skrajnych poglądów. W pierwszym przypadku będą to republikanie, w drugim - Iojaliści.

Pytanie o polityczną przyszłość Irlandii Północnej to także pytanie o tożsamość etniczną aktorów społecznych. Mity, symbole grupowe, stereotypy, wzorce osobowe etc. składają się W pewną całość, kształtując tożsamość grupową, ale także poczucie więzi. W tym kontekście istotne wydaje się pytanie, po pierwsze: jak dalece i w jakim stopniu tożsamości grupowe obu aktorów definiowała walka z wrogiem? Drugie pytanie, wynikające z powyższego, brzmi: jak dalece proces pokojowy (społeczności protestanckiej w dużym stopniu narzucony przez liderów politycznych) wymusza na obu społecznościach redefinicję dotychczasowych tożsamości grupowych? I w jakim zakresie?

\section{HISTORIA KONFLIKTU W ULSTERZE}

"Kłopoty" (The Troubles - określenie, jakie konfliktowi nadała brytyjska administracja rządowa; znamienne jest określenie używane przez nacjonalistów - „wojna”) niewątpliwie zaczęły się na długo przed formalno-politycznym podziałem wyspy. Podział ekonomiczny i kulturowo-religijny był silnie zakorzeniony przed 1921 r. Wielu badaczy (m.in. Rowthorn, Wayne 1988; O'Day 1997; Gruszka 1977) za historyczne podłoże konfliktu uznaje wiek XVII i okres intensywnej kolonizacji Ulsteru (tzw. „Plantation”) przez lojalnych protestantów brytyjskich, głównie szkockich prezbiterian, połączony z wyrzucaniem z ziemi i ograniczaniem praw irlandzkich katolików.

Jak piszą Bob Rowthorn i Naomi Wayne (1988), w południowej części Irlandii owi protestanccy przybysze stanowili tylko powierzchniową, cienką warstwe posiadaczy ziemskich i administratorów, a „pod nimi znajdowała się szeroka masa katolickich pracowników i farmerów. Oznaczało to wyłonienie się dobrze zdefiniowanej różnicy klasowej pomiędzy osadnikami (settlers) a rdzennym Irlandczykami (natives), tak więc większość konfliktów pomiędzy nimi stanowity także konflikty klasowe" (s. 18-19). Sytuacja w północno-wschodniej części kraju była odmienna, funkcjonowały tam silne ośrodki protestanckie, złożone z zamożnych potomków protestanckich imigrantów. Nowi przybysze, pomimo podzielania tej samej wiary, rozpraszali się po wszystkich klasach społecznych, czyniąc z konfliktu religijnego konflikt wewnątrzklasowy - farmerzy czy robotnicy katoliccy i protestanccy walczyli o tę samą pracę lub ziemię.

Czynnikiem identyfikującym „swojego" lub „obcego" stało się wyznanie religijne, które określało jednostkę jako wroga lub sprzymierzeńca. Funkcjonujące prawo i władze nagradzały przynależność do Kościoła protestanckiego, m.in. poprzez przyjmowanie na wysokie stanowiska tylko protestantów, ułatwianie im działalności politycznej i gospodarczej, czy wreszcie ograniczanie praw i wolności katolików, w tym prawa do praktykowania wiary 
katolickiej. Z drugiej strony w chwilach zrywu narodu irlandzkiego (czy też raczej najwybitniejszych i najpotężniejszych rodów gaelickich i ich przywódców) do walki o odzyskanie wolności, protestant utożsamiany był z Anglią (o kształtowaniu patriotyzmu oraz wizji narodu irlandzkiego, wykluczaniu z niego protestantów: por. Kula 1988, 1989), i najeźdźcą i czasami srogo płacit za swe przywileje - np. podczas powstania w Ulsterze w 1641 r. (oraz wcześniejszych), poparcia jakiego udzielili Irlandczycy Jakubowi II w walce z Wilhelmem Orańskim, licznych powstań, czy wreszcie w wyniku działalności IRA (Konarski 1991).

Trudno się dziwić obawom protestantów dotyczącym koncepcji autonomii dla Irlandii, podniesionej pod koniec XIX w. Dla nich „Home Rule” oznaczały „Rome Rule”, czyli rządy hierarchii kościelnej, rzymskiej w (potencjalnie) niepodlegtej Irlandii. Protestanci obawiali się prześladowań i dyskryminacji z powodów religijnych, a także utraty dominującej pozycji ekonomicznej.

Irlandzka rewolucja przemysłowa skupiła się w przeważającej mierze na terenie Ulsteru. Od XVII i XIX w. prężnie rozwijał się przemyst tekstylny, a także stoczniowy. Belfast i jego okolice na początku XX w. były najlepiej prosperującym rejonem Zjednoczonego Królestwa. W porównaniu z resztą wyspy, biedną i zacofaną, obszary te stanowiły niezwykle atrakcyjne miejsce dla poszukujących pracy i chleba chłopów.

Protestanccy robotnicy, stojąc w obliczu zalewającej Ulster taniej sity roboczej, zaczęli walczyć o zachowanie lepszych i lepiej płatnych miejsc pracy dla siebie - protestanccy pracodawcy przyjmowali na wyższe stanowiska tylko współwyznawców, z czasem swoistym rynkiem pracy stał się Zakon Orański (Orange Order).

Irlandia Północna powstała w 1922 r., na podstawie umowy angielsko-irlandzkiej z 1921 r. Z obszaru Irlandii zostało wyłączone sześć hrabstw Ulsteru (historycznie prowincja liczy dziewięć), na terenie których protestanci stanowią demograficzną większość: Antrim, Down, Armagh, Fermanagh, Tyrone i Derry. Ustanowienie "Irlandii Północnej" było politycznym sukcesem przedstawicieli i negocjatorów pochodzących z milionowej mniejszości ulsterskich unionistów - „lojalnych” zwolenników zachowania unii z Wielką Brytanią. Z drugiej strony sygnatariusze porozumienia anglo-irlandzkiego, zarówno rząd brytyjski jak i negocjatorzy ze strony Irlandii, traktowali zaistniałą sytuację jako przejściową, spodziewając się rychłego zjednoczenia północy z południem wyspy.

Pierwsze lata funkcjonowania państwa północnoirlandzkiego ubiegły pod znakiem formowania struktur administracyjnych oraz instytucji rządowych. Decydującą rolę odgrywała w tych procesach unionistyczna większość i jej polityczni przedstawiciele. Główną ideą a jednocześnie celem unionistycznych partii politycznych, takich jak Democratic Unionist Party (DUP) czy Ulster Unionist Party (UUP), było prawne zagwarantowanie dominującej pozycji unionistów, kosztem praw republikańskiej i nacjonalistycznej mniejszości.

Centralnym elementem polityki państwa wobec mniejszości katolickiej oraz jednocześnie głównym narzędziem represji był uchwalony przez Stormont w 1922 r. Akt Specjalnych Uprawnień - Civil Authorities (Special Powers) Act. Na jego mocy brytyjski minister spraw wewnętrznych mógł podejmować wszelkie kroki niezbędne dla utrzymania pokoju i porządku, takie jak aresztowanie i przesłuchiwanie bez podania przyczyn, internowanie na czas nieokreślony (bez procesu sądowego), kara śmierci dla członków bojówek, przeszukiwania mieszkań bez nakazów, sprawdzanie przez rząd prywatnych kont bankowych, nałożenie cenzury na mass-media itd. Akt ten był przedłużany o kolejne pięć lat.

Sądownictwo Północnej Irlandii składało się głównie z protestantów, otwarcie podkreślających swoją przynależność do partii unionistycznej. Sprawowanie funkcji sędziego czy przysięgłego uzależniono od posiadania własności, a katolicy/nacjonaliści posiadali mniej 
domów, ziemi itp. (Hillyard 1983: 35). W ten sposób wiązano sprawowanie ważnych spotecznie funkcji z przynależnością oraz poczuciem lojalności (a także okazywaniem jej m.in. poprzez wydawanie "słusznych" wyroków sądowych) wobec grupy własnej, w tym wypadku unionistów.

Narzędziem służącym utrzymaniu nowego porządku i podziału władzy była policja. W jej skład wchodzity: Royal Ulster Constabulary (RUC) oraz Ulster Special Constabulary (USC). Regularną siłę policyjną stanowiło RUC, złożone w przeważającej części z protestantów pomimo początkowego założenia, że katolicy mają stanowić trzecią część sił. Na skutek działań policji, liczba katolików w tych siłach od początku była niewielka i ciągle spadała (w 1969 r. wynosiła 11\%). Ulster Special Constabulary, powszechnie znaną jako B Specials, utworzono w 1920 r. na bazie protestanckiej bojówki, Ulster Volunteer Force (UVF). RUC była traktowana przez obie strony, katolików i protestantów, jako „zbrojne ramię" większości protestanckiej, siła stabilizująca i umacniająca istniejący podział władzy, narzędzie represji i dominacji. Jedną z policyjnych metod walki z nacjonalistami było „strzelanie, żeby zabić" (shoot to kill), co szczególnie brutalnie przejawiało się w licznych przypadkach zastrzelenia nieuzbrojonych członków IRA lub INLA (Irish National Liberation Army) (Rowthorn, Wayne 1988: 58-60). Policja używała także plastikowych pocisków, które nie tylko straszliwie raniły atakowanych, ale także zabijały (Rowthorne, Wayne 1988: 60).

W latach 50. i na początku lat 60. społeczność katolicka wydawała się coraz bardziej zmęczona walką i bezowocnym czekaniem na zjednoczenie Irlandii. Wyrazem społecznego znużenia był zwrot zainteresowania w stronę lokalnych, niepolitycznych problemów i spraw związanych z codziennym funkcjonowaniem. Wiązały się z tym także oczekiwania uzyskania korzyści płynących z procesów modernizacji, jakim - głównie za przyczyną brytyjskiej polityki wewnętrznej i inwestycji - podlegała wówczas Irlandia Północna. Symptomem zmiany postawy społeczności katolickiej był spadek poparcia dla IRA.

Koniec lat 60. to czas „fermentu” społecznego i wielkich emocji. To także okres obywatelskich marszów katolików domagających się swoich praw obywatelskich. Głównym celem tych pokojowych manifestacji było zwrócenie uwagi władz na nierówny podział dóbr i profitów płynących z modernizacji kraju, a także na praktykę dyskryminacji katolików w sferze socjalnej. Pierwszy marsz, zorganizowany w marcu 1968 r. przez NICRA (Northern Ireland Civil Rights Association) na trasie z Coalisland do Dungannon, z udziatem kilku tysięcy osób, miał charakter pokojowy. Kolejne, m.in. marsz w Derry/Londonderry, spotykały się z niechęcią lokalnych władz oraz agresją ze strony protestanckich bojówek, np. The Apprentice Boys of Derry (Organizacji Czeladników Derry).

Premier Irlandii Północnej Terence O’Neill, w odpowiedzi na "gorącą" sytuację w prowincji, zainicjowat szereg reform, m.in. zmiane granic wyborczych i wprowadzenie zasady „jeden człowiek - jeden głos" w wyborach lokalnych, rozbrojenie RUC i wprowadzenie bardziej reprezentatywnej siły policyjnej, ustanowienie nowych organów ds. mieszkalnych, przyjęcie obiektywnego systemu przyznawania mieszkań. Jednakże proponowane reformy nie spełniały oczekiwań mniejszości katolickiej.

W odpowiedzi na niepokoje społeczne, w 1969 r. rząd brytyjski oficjalnie przejął władzę w Irlandii Północnej. Na wyspę wysłano brytyjskie wojsko, które miało zaprowadzić ład i porządek. Trzeba dodać, że ta decyzja spotkała się z aplauzem ze strony katolików, którzy potraktowali żołnierzy jako obrońców.

Lata 70. to okres narastania i rozwijania się konfliktu; coraz częściej dochodzi do starć zbrojnych, giną ludzie. Do konfrontacji dochodzi głównie między wojskiem brytyjskim i policją a Irlandzką Armią Republikańską (IRA), która przyjęła rolę obrońcy społeczności 
katolickiej. Główną metodą walki IRA jest podkładanie bomb i organizowanie zamachów na wybitne osobistości (np. zamordowanie lorda Mountbattena, nieudany zamach na Margaret Thatcher). W odpowiedzi rząd brytyjski zaostrza represje, a bojówki protestanckie odpowiadają IRA tą samą monetą.

Początek walk pomiędzy republikanami a wojskami brytyjskimi przypada na 1970 r. Obchody rocznicy powstania wielkanocnego w Derry/Londonderry, Belfaście i Armagh zamieniają się w zamieszki. Dochodzi do rozłamu w IRA - organizacja dzieli się na IRA oficjalną (Officials), która podejmuje rozmowy z protestantami i rezygnuje z walki zbrojnej, oraz na Provisional IRA (Provos) - Tymczasową IRA, która nadal podąża drogą walki. Zamieszki, podkładanie bomb trwają przez całą dekadę (Gruszka 1986; Konarski 1991). Najstynniejszym wydarzeniem tego okresu jest "Krwawa Niedziela" (Bloody Sunday).

Próbą opanowania wymykającego się spod kontroli konfliktu był Criminal Justice (Temporary Provision) Act, uchwalony w 1970 r. Na jego mocy można było skazywać na karę sześciu miesięcy więzienia każdego, kogo oskarżono o zachowanie niezgodne z zasadami porządku społecznego, mogące wywołać rozruchy (Rowthorn, Wayne 1988: 42).

W sierpniu 1971 r. rząd wprowadzit instytucję internowania bez wyroku sądowego. W 1972 r. Westminster przejmuje bezpośrednią władzę na terenie Irlandii Północnej. Zmniejsza się liczba internowanych bez procesu, prawo to zostaje zastąpione przez "Diplock Courts" (sądy bez ławy przysięgłych, wyrok wydaje sędzia). Rząd brytyjski uznaje konflikt za sprawę o charakterze politycznym i nawiązuje kontakt z Republiką Irlandii w celu obopólnego rozwiązania „problemu”. W latach 1972-1974 rząd brytyjski podejmuje inicjatywę mającą doprowadzić do pokojowego rozwiązania konfliktu (tzw. I proces pokojowy). Z powodu braku poparcia ze strony lokalnych partii politycznych, po obu stronach, przedsięwzięcie upada.

Wielokrotnie w trakcie trwania konfliktu władze brytyjskie podejmują próby pokojowego zakończenia walki pomiędzy obiema społecznościami, w szczególności nacjonalistami i lojalistami. Wydaje się, że administracja rządowa chciała jak najszybszego rozwiązania kłopotliwej dla siebie sytuacji, za jaką uważano konflikt w Ulsterze. Strona brytyjska wielokrotnie zapewniała, że nie ma żadnych żywotnych interesów - ekonomicznych i politycznych - w Irlandii Północnej. Wydaje się, że była wielce niechętna włączaniu się administracji w niezrozumiałe problemy „,irlandzkiego zaścianka” (Irish bog - dosłownie oznacza „irlandzkie bagno", por. Dixon 2000). Z tej perspektywy zjednoczenie Irlandii wydawało się zainteresowanym stronom, w tym także rządowi irlandzkiemu, rozsądnym rozwiązaniem, któremu w zasadzie przeciwstawiała się jedna znacząca siła - blisko milionowa społeczność ulsterskich protestantów.

Nowa, laburzystowska administracja brytyjska uznaje, że "The Troubles" nie są sprawą polityczną a społeczną. W związku z tym dochodzi do zwalniania internowanych i zniesienia statusu specjalnej kategorii dla wszystkich więźniów republikańskich skazanych po marcu 1976 r. Od tej pory są oni traktowani jako zwykli kryminaliści - proces ten określa się jako „kryminalizację" (criminalization) Ulsteru. Dochodzi również do „Ulsteryzacji” (UIsterization) prowincji - rząd brytyjski przekazuje odpowiedzialność za porządek i ochronę prowincji z armii na lokalne siły porządkowe (Rowthorne, Wayne 1988: 44-46; Hillyard 1983: 44-48).

Odebranie więźniom republikańskim statusu specjalnej kategorii i zrównanie ich ze zwykłymi przestępcami (co m.in. oznaczało noszenie więziennego munduru - do tej pory więźniowie polityczni mogli nosić własne ubrania) spotkało się z ostrym sprzeciwem z ich strony. Jego wyrazem był „brudny protest” (dirty protest), który polegał na odmawianiu 
sprzątania nieczystości w celach republikanów. W roku 1980 w więzieniu dla groźnych przestępców (głównie republikanów) w Maze siedmioro więźniów rozpoczęło strajk głodowy przeciwko „kryminalizacji”. Po kilku dniach dołączyły do nich współwięźniarki z Armagh. Symbolem walki stał się Bobby Sands, dowódca Tymczasowej IRA, więziony w Maze, który 1 marca 1981 r. rozpoczął strajk głodowy przeciwko zniesieniu statusu więźnia politycznego (Sands 1990).

Strajk i śmierć Bobby'ego Sands'a stały się elementem w grze politycznej i walce ideologicznej pomiędzy IRA a brytyjskimi władzami, dając miażdżące moralne zwycięstwo IRA, która odzyskała, a nawet zwiększyła poparcie wśród społeczności katolickiej.

Lata 80. i 90. to kolejne niespokojne dekady. Nasilają się akcje podejmowanie zarówno przez bojówki nacjonalistyczne, jak i lojalistyczne. Podkładanie bomb, morderstwa na tle politycznym, akcje terrorystyczne stają się narzędziami w walce politycznej, argumentami mającymi wzmocnić racje oraz pozycję polityczną nacjonalistów z jednej, a lojalistów z drugiej strony.

W tym czasie dochodzi do podpisania międzyrządowej umowy, tzw. Anglo-Irish Agreement (1985 r.), na mocy której rząd brytyjski gwarantował systematyczny i zinstytucjonalizowany wpływ rządu Republiki Irlandii na sprawy Irlandii Północnej. Z kolei rząd irlandzki zgodził się na to, że status prawny i polityczny Irlandii Północnej może zostać zmieniony wyłącznie wolą większości jej obywateli.

Nacjonaliści jednak dążą - z sukcesem - do utworzenia „pan-nacjonalistycznego" forum/frontu międzynarodowego, do którego włącza się nie tylko Republika Irlandii, ale także rząd Stanów Zjednoczonych, tworząc w ten sposób silną grupę nacisku i lobbowania na rzecz zjednoczenia Irlandii. Ważnym aktorem staje się Sinn Feinn, a szczególnie jej liderzy, Gerry Adams i Martin McDonald. Zgodnie z taktyką bullet and ballot box (kula i urna wyborcza) Sinn Feinn rezygnuje z dotychczasowej, tradycyjnej strategii politycznej, polegającej na odmawianiu przyjmowania mandatów przez posłów tej partii i włącza się w życie polityczne zarówno na poziomie lokalnym jak i parlamentu brytyjskiego. Zyskuje dzięki temu nowe możliwości propagowania i dochodzenia swoich interesów. Z drugiej strony liderzy Sinn Feinn podporządkowują sobie władze IRA, dzięki czemu mogą - do pewnego stopnia - kontrolować jej działania, zyskując jednocześnie kolejne narzędzie w walce politycznej. Przykładem może być zawieszenie broni, ogłoszone przez IRA w 1994 r., oraz jego przerwanie w roku 1996, w niekorzystnym politycznie dla Sinn Feinn momencie.

Efektem politycznych nacisków, negocjacji pomiędzy stronami oraz ulsterskimi partiami politycznymi, presji ze strony społeczności międzynarodowej (Stanów Zjednoczonych oraz Unii Europejskiej) było podpisanie 10 kwietnia 1998 r. pokojowego porozumienia pomiędzy największymi ulsterskimi partiami politycznymi oraz rządami brytyjskim i irlandzkim, tzw. Good Friday Agreement. Ustanawiało ono nowy podział formalnej i politycznej władzy w Irlandii Północnej: zapowiadało utworzenie nowego parlamentu, Northern Irish Assembly, złożonego z przedstawicieli najważniejszych i najliczniejszych partii politycznych. Interesy mniejszości miały być chronione przez ciało złożone z przedstawicieli władz północy i południa wyspy, o szerokich uprawnieniach (North-South Ministerial Council). RUC miało zostać poddane radykalnej reformie. Dla poprawy relacji pomiędzy dwiema społecznościami utworzono szereg ciał, takich jak Human Rights Commission, Equality Commission, a także Northern Ireland Victims Commission, przyjęto też Bill of Rights for Northern Ireland, sformułowane na bazie europejskiej konwencji praw człowieka.

Good Friday Agreement zostało przyjęte przez obywateli Irlandii Północnej w referendum: przy wysokiej frekwencji - 81\%, poparło porozumienie $71,1 \%$ głosujących, zaś 
28,8\% je odrzuciło (por. Dixon 2001: 273). Porozumienie zostało przyjęte, także na drodze ogólnonarodowego referendum, w Republice Irlandii. Konsekwencją tego faktu było wykreślenie w 1999 r. z konstytucji Republiki art. 2 i 3, mówiących, że „terytorium narodowe obejmuje całą wyspę Irlandię, jej wyspy i morza terytorialne" (por. Constitution of Ireland, 1937).

Przyjęcie przez wszystkie zainteresowane strony porozumienia wielkopiątkowego nie zmniejszyło wzajemnych pretensji i nieufności. Przywódcy partyjni starali się przedstawiać je swoim wyborcom jako sukces, odmiennie interpretując jego postanowienia. Dla nacjonalistów był to kolejny, znaczący krok w kierunku zjednoczenia Irlandii, dla unionistów gwarancja pozostania w unii z Wielką Brytanią. Przyjęcie porozumienia nie zakończyło walki na ulicach, zamachów i ataków, podkładania bomb (na terenie Ulsteru, Republiki oraz Wielkiej Brytanii) przez bojówki obu stron (te organizacje paramilitarne, które nie uznały porozumienia, takie jak Real IRA, Continuity IRA) czy militarnych interwencji stacjonujących w Ulsterze wojsk brytyjskich. Pomimo to główni aktorzy polityczni - przedstawiciele rządów brytyjskiego i irlandzkiego oraz największe partie polityczne - prowadzili rozmowy i osiągali kolejne porozumienia konkretyzujące podział władzy, a także reformę policji, sądownictwa czy rozwiązania na szczeblu rządowym problemu parad oranżystów, w celu zapobiegania starciom pomiędzy nacjonalistami a lojalistami (m.in. majowe porozumienie Hillsborough Castle Agreement). Ważnym, symbolicznym i politycznym, krokiem była demilitaryzacja oraz otwarcie i udostępnienie arsenałów broni przez IRA (wrzesień 2005 r.).

Wpływ polityki na społeczne postrzeganie i interpretacje historii, a raczej wybranych faktów historycznych, widać najwyraźniej na obszarze ideologii. Ideologia jest jedną z dróg konstruowania społecznej rzeczywistości, szczególnie użyteczną w konflikcie, gdyż opis świata, którego dostarcza, pretenduje do miana ostatecznego, końcowego. Dostarczając absolutnych odpowiedzi na wszystkie pytania, dostarcza jednocześnie etykietek dla innych, definiując ich i opisując prawdziwą tożsamość (Mach 1989).

Sam proces powstawania struktur państwowych Irlandii Północnej był efektem ideologii, umiejętnie podsycającej lęk protestantów przed suwerennym państwem irlandzkim. Uzyskanie niepodległości przez Irlandię i ustanowienie niezależnego państwa irlandzkiego było postrzegane przez unionistów i lojalistów jako zagrożenie dla ich wolności (także wolności wyznania). Lęk podsycała też obawa przed nowym porządkiem politycznym i społecznym, a także przed utratą przywilejów i dominującej pozycji. Utrzymanie unii w Wielką Brytanią miało stanowić gwarancję zachowania dotychczasowego ładu społecznego i politycznego. Także na poziomie tożsamości kulturowej idea „brytyjskości” była przedstawiana jako główny wyznacznik, czynnik konstytuujący tożsamość grupową; walka o zachowanie unii miała też symboliczny wymiar walki o możliwość „bycia sobą", zachowania i praktykowania tożsamości grupowej.

W relacjach pomiędzy protestantami a katolikami, szczególnie u tych pierwszych nasilał się syndrom "oblężonej wyspy". Wrogiem w tym układzie była mniejszość katolicka, przede wszystkim republikanie i nacjonaliści, ale także władze Republiki, dążące do zjednoczenia wyspy. Konieczność „obrony" przed wrogimi i dysydenckimi, a przede wszystkim "nielojalnymi” (względem nowego państwa) katolikami wyrażała się także w ustawodawstwie i prawodawstwie północnoirlandzkim oraz w instytucjach administracji rządowej, począwszy od działalności parlamentu Stormont, skończywszy na policji RUC.

Z drugiej strony nacjonaliści i republikanie, a do pewnego stopnia także członkowie międzynarodowego "frontu pannacjonalistycznego" nieustannie podkreślali konieczność 
politycznego zjednoczenia wyspy. Zasadą naczelną leżąca u podstaw nacjonalistycznej i republikańskiej ideologii jest przekonanie o nieuchronności i konieczności zjednoczenia Irlandii. Ulsterscy unioniści i lojaliści są w niej przedstawiani jako najeźdźcy, a w łagodniejszej wersji goście, nigdy zaś pełnoprawni mieszkańcy prowincji. Stąd też odmowa uznania i legitymizacji stworzonego przez protestanckie władze porządku społecznego, ale także odmowa moralnego prawa do ziemi, którą protestanci nazywają ojczyzną.

Podstawy ideologii unionistów i lojalistów są niejako zwierciadlanym odbiciem przekonań przeciwników. Ulsterscy protestanci mają wszelkie - formalne i moralne prawa - do Ulsteru; prawa nabyte w konsekwencji wygranej przez Wilhelma Orańskiego bitwy nad Boynne. To zwycięstwo legitymizuje władzę protestantów w Ulsterze. O wadze tego faktu historycznego, a raczej jego interpretacji, świadczyć mogą odbywane corocznie, w różnych częściach kraju, marsze członków Zakonu Orańskiego. Parady oranżystów z orkiestrą, flagami i symbolami, nieustannie, w cyklicznym rytmie (mitycznym i rytualnym?) na nowo symbolicznie ustanawiają i legitymizują istniejący porządek społeczny.

W ideologii partii politycznych i organizacji paramilitarnych przyjmowana i prezentowana wizja historii służy zdobywaniu wyborców oraz ich mobilizowaniu, na przykład podczas wyborów lokalnych lub parlamentarnych. Z drugiej strony owa polityczna interpretacja historii albo wybranych faktów historycznych ma potwierdzać, niejako "dokumentować" zasadność i prawdziwość ideologii.

Bez wątpienia historia - i to zarówno ta odległa, sprzed kilku lub kilkunastu wieków, jak i najnowsza historia konfliktu, historia "wojny”, a także poległych w tej "wojnie” ofiar jest ważną częścią życia społecznego, także w sferze życia codziennego. Jest elementem teraźniejszości. Dlatego tak istotne jest, aby dwie wizje historii, dwie imagined histories, pozostawiały przestrzeń dla koegzystencji, współżycia obu społeczności. Wydaje się, że sytuacja wymusza na liderach obu społeczności - ostrożne i stopniowe - reinterpretacje historii, szczególnie jej zideologizowanych wersji.

\section{DYSKRYMINACJA, CZYLI WPISANIE KONFLIKTU W STRUKTURĘ SPOLECZNĄ}

W książce Ethnicity Glazer i Moynihan zauważyli, że „w przeszłości konflikt religijny, taki np. jak ten, który rozdziera Irlandię Północną, dotyczył kwestii związanych z nieskrępowanym, publicznym praktykowaniem religii. Dzisiaj wiąże się ze sporem, która z grup będzie odnosić korzyści albo sprawować władzę najzupełniej świecką" (1975: 7). Trudno stwierdzić, do jakiego okresu historycznego odnoszą się przywoływani autorzy, bo niewątpliwie w historii Irlandii zdarzały się momenty, w których walka z angielskim najeźdźcą przyjmowała formę walki o możliwość praktykowania religii katolickiej.

Zacytowany powyżej fragment można także odczytać w nieco innym świetle, ukazującym niereligijne interpretacje konfliktu. Jednym z teoretycznych podejść, płaszczyzną analizy konfliktu i jego przyczyn, jest podejście strukturalno-instytucjonalne, oparte na paradygmacie neomarksistowskim. Zwolennicy tegoż argumentują, iż „prawdziwą” przyczyną konfliktu w Ulsterze jest konflikt interesów pomiędzy protestantami a katolikami. Nie ma on jednak charakteru antagonizmu klasowego, jest to raczej konflikt w obrębie poszczególnych klas - a szczególnie robotniczej - w których dochodzi do starć pomiędzy protestantami a katolikami walczącymi o to samo miejsce pracy czy o świadczenia socjalne, np. otrzymanie mieszkania socjalnego. 
Walka o dobra czy władze przebiega na wszystkich poziomach hierarchii i struktury społecznej. W walce tej dominującą i uprzywilejowaną pozycję mieli protestanci. Unioniści, korzystając ze wsparcia Wielkiej Brytanii, zdominowali polityczne, ekonomiczne i kulturowe siły, objęli kontrolę nad drogami komunikacji z Westminsterem, w końcu stworzyli państwo, które miało ochraniać ich interesy na Wyspie. Z kolei nacjonaliści, którzy od początku (tzn. od 1921 r.) odmawiali uznania legalności Irlandii Północnej, zostali zakwalifikowani jako „nielojalni”, pozbawieni udziału w państwie oraz poddani dyskryminacji ekonomicznej, politycznej i kulturowej. Polityka „oblężonej twierdzy” doprowadziła do zepchnięcia katolików na margines życia społecznego.

Obie społeczności zostały złapane w strukturalną pułapkę - fundamentalne interesy jednej z nich mogły być zagwarantowane tylko kosztem fundamentalnych interesów drugiej (Ruane, Todd 1993: 34).

Wzajemne stosunki przedstawiane są zazwyczaj w kontekście dominacji i dyskryminacji. Badacze skupiają się najczęściej na wyróżnionych poniżej obszarach życia społecznego i politycznego.

Dyskryminacja polityczna wiązała się między innymi z systemem wyborczym do lokalnych władz, określanym mianem gerrymandering (Gruszka 1986: 35). Na mocy tego prawa okręgi wyborcze zostały wytyczone w taki sposób, że na terenach zamieszkanych w większości przez katolików tworzono wielkie, jednomandatowe okręgi wyborcze, a na terenach zdominowanych przez protestantów okręgi małe, wielomandatowe. Przykładem tego były wybory do Stormontu (parlament Irlandii Północnej) w 1949 r., gdy w hrabstwie Fermanagh, zamieszkiwanym w większości przez społeczność katolicką, utworzono trzy jednomandatowe okręgi wyborcze. Jeden obejmował większość katolików, głosujących tradycyjnie na partię nacjonalistyczną, a pozostałe dwa, z mniejszą liczbą wyborców, cechowała nieznaczna przewaga protestantów. W efekcie dwaj postowie protestanccy otrzymali razem 13895 głosów, a jeden poseł katolicki 15582 głosy (Gruszka 1986: 35).

Gerrymandering został dodatkowo wzmocniony przez business premises vote, tzn. instytucję głosowania pluralistycznego, która umożliwiała właścicielom przedsiębiorstw oddawanie dodatkowych głosów. Oprócz tego istniało graduate vote, które dawało prawo wyboru czterech postów do Stormontu przez pracowników naukowych i absolwentów Queen's University w Belfaście (Gruszka 1977: 76). W tym samym czasie prawo głosu posiadali tylko właściciele majątku lub nieruchomości, z wyjątkiem domu mieszkalnego, oraz właściciele lub dzierżawcy domu mieszkalnego (nie mieszkania) w danym okręgu wyborczym (Gruszka 1977: 79).

Dyskryminacja w przyznawaniu mieszkań socjalnych stała się jedną z głównych przyczyn powstania w roku 1968 społecznego ruchu Praw Obywatelskich.

„W 1944 r. badania rządu północnoirlandzkiego pokazały, że 39\% wszystkich mieszkań w prowincji wymagało natychmiastowego remontu lub zamiany. W hrabstwie Fermanagh, w którym sytuacja była najgorsza, w mieście Enniskillen 43,7\% mieszkań wymagało zamiany, zaś na obszarach wiejskich odsetek ten wynosit ponad 50 . Było to niewątpliwie spowodowane tym, że w latach 1921-1945 nie pobudowano na tym terenie żadnych nowych mieszkań. W okresie następnych 22 lat zbudowano 1048 nowych budynków mieszkalnych. W tym rejonie, zdominowanym przez katolików i to katolików biedniejszych i bardziej potrzebujących nowych domostw, otrzymali oni 195 mieszkań (18\%), a pozostałe 853 (82\%) dostali protestanci" (Rowthorn, Wayne 1988: 31).

Powodem, dla którego Rada hrabstwa Fermanagh nie budowała przez lata nowych mieszkań (podobnie jak wiele innych rad), było pragnienie niezakłócania politycznego ba- 
lansu sił związanego z aktualnym ukształtowaniem okręgów wyborczych. Dlatego też katolicy nie otrzymywali mieszkań w dzielnicach protestanckich, ponadto próbowano ograniczać liczbę katolików w rejonach wyborczych, właśnie poprzez brak mieszkania, chociaż ze względu na generalnie niższy status materialny i niższe dochody, katolicy częściej ubiegali się o pomoc socjalną, między innymi w postaci mieszkań komunalnych.

Spis Powszechny z 1971 r. pokazał, że katolicy rzadziej niż protestanci posiadali mieszkania na własność lub wynajmowali je prywatnie, natomiast znacznie chętniej korzystali z publicznego wynajmu. Ponadto mieszkania katolików częściej pozbawione były podstawowych udogodnień, jak ciepła woda, łazienka z toaletą, prysznicem i wanną (Melaugh 1995).

Dyskryminacja mniejszości katolickiej widoczna była również w dzie dzinie za trudnienia. Populację katolicką charakteryzował permanentnie wyższy poziom bezrobocia. Spis Powszechny z 1991 r. wykazał, że bezrobocie wśród mężczyzn - katolików wynosiło 28,4\%, w porównaniu z 13,9\% wśród protestantów i innych kategorii. W przypadku kobiet różnice wynosiły 13,9\% (katoliczki) oraz 8,8\% (protestantki). Badania z innych źródeł potwierdzają te dysproporcje (Melaugh 1995: 134). Katolicy zajmowali gtównie niskopłatne stanowiska, pracując jako np. robotnicy niewykwalifikowani, natomiast protestanci zajmowali wyższe stanowiska (np. administratorów, managerów) (Melaugh 1995: 135; Rowthorn, Wayne 1988: 34-35).

O ile sektor państwowy, publiczny, jest kontrolowany przez władze brytyjskie i skłaniany do zapobiegania dyskryminacji, o tyle w sektorze prywatnym jest ona niczym nie skrępowana. Pracodawców publicznie zachęcano do zatrudniania tylko współwyznawców, a największa organizacja protestancka, Zakon Orański (Orange Order), stanowi swoisty rynek pracy, gdzie potencjalni pracownicy rekomendowani są jako dobrzy protestanci. O rozmiarze zjawiska może świadczyć wypowiedź sir Basila Brooke'a, byłego premiera rządu w Irlandii Północnej, zachęcającego lojalistów do zatrudniania, gdziekolwiek to możliwe, "dobrych protestanckich pań i panów”, czy też polecającego „tym, którzy są lojalistami, niezatrudnianie rzymskich katolików, którzy w 99\% są nielojalni" (Rowthorn, Wayne 1988: 33). Dyskryminacja działała także w drugą stronę - katoliccy przedsiębiorcy niechętnie zatrudniali protestanckich pracowników.

Bob Rowthorne i Nayomi Wayne (1988: 34) wymieniają pięć głównych mechanizmów dyskryminacji, dzięki którym relacje dotyczące zatrudnienia nie zmieniły się od XIX W. Zdaniem autorów: większość zakładów przemysłowych była ulokowana w miejscach niebezpiecznych lub trudno dostępnych dla katolików; katolicy poszukujący pracy byli niechętnie zatrudniani; katolicy przestawali ubiegać się o pracę w przedsiębiorstwach, które zdobyły reputację niezatrudniających katolików; niektóre związki zawodowe działały jako ukryci agenci, tworząc ukrytą, aczkolwiek efektywną barierę przeciwko zatrudnianiu katolików; często nie dochodziło do publicznej rekrutacji. Pracodawcy polegali na „zatrudnianiu ustnym" (word-of-mouth hiring) opartym na zatrudnionych pracownikach (którzy informowali o wakatach rodzinę i przyjaciół) oraz na innych kontaktach społecznych (np. Zakon Orański).

Dyskryminacja przejawiała się także na innych płaszczyznach, jak choćby we wspomnianej wcześniej praktyce ustawodawczej (interesująca jest w tym kontekście lektura książeczki wydanej przez Norweski Komitet Helsiński Prawa człowieka w Irlandii Północnej, 1991).

Znaczenie dyskryminacji bywa podkreślane przez badaczy interpretujących konflikt w kategoriach konfliktu klasowego. Zaobserwowano pewną prawidłowość dotyczącą strukturalnej i klasowej identyfikacji osób biorących aktywny udział w atakach - w więk- 
szości zwolennikami i uczestnikami bojówek po obu stronach są robotnicy. Wydaje się, że członkowie klasy średniej, pomimo wyraźnych identyfikacji etniczno-religijnych, w inny, bardziej pokojowy i koncyliacyjny sposób wyrażają ową odmienność. Argumenty te wysuwa się jako potwierdzenie tezy o materialnym podłożu konfliktu.

Wydaje się, że zarówno niedocenianie jak i przecenianie czynnika materialnego, ekonomicznego, może zniekształcić analizę stosunków społecznych. Deprywacja sama w sobie nie jest czynnikiem wywołującym czy inicjującym konflikty społeczne. Poczucie deprywacji może integrować grupę, pośrednio przyczyniając się do mobilizacji jej członków. Pod warunkiem jednak, że grupowi ideolodzy wskażą winnych tego stanu, włączając biedę, niskie zarobki czy brak perspektyw zawodowych do listy grzechów i przewinień, jakich grupa podporządkowana doświadcza ze strony grupy dominującej.

Nie można nie wspomnieć o części społeczności katolickiej, która przeniosła się z biednych gett do zamożnych dzielnic klasy średniej, wpisując się w gospodarcze i polityczne życie kraju. Niektórzy z katolickich polityków, jak np. laureat pokojowej nagrody Nobla, John Hume, walcząc (w ramach istniejącego systemu politycznego) o prawa dla katolików, nie mówi o przyłączeniu Ulsteru do Republiki Irlandii, ale o tworzeniu wspólnoty obejmującej obie grupy. Z drugiej strony katolicy, którzy zdecydują się na ucieczkę z getta i na asymilację, muszą zgodzić się na przyjęcie kulturowych wzorów "brytyjskości” oraz stylu życia dominującej protestanckiej klasy średniej (Ruane, Todd, 1993: 192). Z kolei wielu protestantów, ceniących sobie swój status ekonomiczny i specyfikę kulturową związaną z „północnym protestantyzmem”, krytycznie odnosi się do niektórych przejawów dominacji brytyjskiej, np. do rządu, władz (tamże: 196).

Zawężanie przyczyn i źródeł konfliktu do czynników materialnych i osadzanie go w kontekście walki klasowej nie pozwala na uchwycenie wyraźnej specyfiki zjawiska. Ważnymi czynnikami kształtującymi i podtrzymującymi ów konflikt są także etniczność oraz religijność społeczeństwa Irlandii Północnej, i bez uwzględnienia ich roli obraz sytuacji, a także jej ocena i ewentualne prognozy dotyczące powodzenia procesu pokojowego będą niepełne. Interesujące są w powyższym kontekście słowa Ursa Altermatta:

„wojna domowa w Irlandii Północnej ze swymi wyznaniowymi frontami nie pasowała wprawdzie do obrazu zlaicyzowanego społeczeństwa zachodnioeuropejskiego, ale obserwatorzy traktowali ją głównie jako konflikt społeczno-ekonomiczny, wtłoczony w marksistowski schemat walki klas, który zdominował myślenie współczesnych intelektualistów. (...) Nacjonalizm o podłożu religijnym był $w$ tym obrazie nie do pomyślenia - i w pewnym sensie nie istniał. (...) Nie bez znaczenia był tu fakt, że Irlandia na mapie europejskiej zajmuje bądź co bądź marginalną pozycję" (1998: 134).

UWIKŁANI W KULTURE??

Zwolennicy interpretacji kulturalistycznej podkreślają odrębność „kultur etnicznych” obu grup, uznając ową odmienność za główną przyczynę konfliktu. Poszczególni badacze wyróżniają rozmaite obszary kultury mające znaczący wpływ na trwanie i intensywność konfliktu.

Jednym z najważniejszych, jeśli nie kluczowym, jest religia. Jest to widoczne między innymi w etykietkach „protestant” i „katolik”, jakie nadają sobie nawzajem, a także przeciwnikom, obie strony. Katolicy stanowią wspólnotę zintegrowaną i scentralizowaną w jeden Kościół - rzymskokatolicki. Protestanci rozdzieleni są pomiędzy wiele wspólnot religij- 
nych, m.in. prezbiterian czy metodystów. Nazwa „kościoły” wydaje się tutaj adekwatna, gdyż oprócz Kościoła rzymskokatolickiego, poza największymi wspólnotami protestanckimi (prezbiterianie i anglikanie), funkcjonuje około 45 odrębnych wyznań (Morrow 1995: 156). Liczebnie największą wspólnotą wyznaniową jest właśnie wspólnota rzymskich katolików. Wydaje się, że pośród dyskryminowanej mniejszości Kościół pełni rolę podobną do tej, jaką odgrywał w Polsce w czasach komunizmu, tzn. obrońcy i reprezentanta w walce o prawa obywatelskie. Jest niewątpliwie najważniejszą instytucją w społeczności katolickiej, choć wielu republikanów zarzucało mu zbytnią ugodowość w stosunku do władz brytyjskich i północnoirlandzkich. Z drugiej strony, oskarżany jest przez te ostatnie o organizowanie republikanizmu (tamże: 158).

Zdaniem Alana Finlaysona, siła i waga religii wynika stąd, że stanowi ona wyraźny i znaczący znak grupy etnicznej i jej aspiracji - w Irlandii Północnej religia definiuje historycznie ugruntowany rdzeń etniczny, wokół którego krystalizowała się tożsamość społeczności (1997: 84). Traktowanie religii jako wyznacznika przynależności do poszczególnych grup ma swoje korzenie w teoriach etniczności, gdzie religia jest jednym z głównych elementów konstytuujących grupę etniczną i tożsamość etniczną (np. Isajiw 1974; Sadowski 1973; Nowicka 1980; Kubiak 1980; Mucha 1980; Posern-Zieliński 2003).

„Polityczna i ideologiczna działalność transformowała to znaczenie religijnej przynależności i w tym sensie religia jest ważna, a wyznanie, wspólnota religijna jest używana jako etykieta dla grup etnicznych" (Finlayson 1997: 84). Jak wspominałam, protestanci traktują Kościół katolicki jako „głównego operatora” wrogiej im społeczności. Kościoły protestanckie mają mniejsze znaczenie jako organizatorzy życia społecznego swoich członków, jednakże to właśnie antykatolicki wymiar protestantyzmu stał się niezwykle istotnym elementem kształtującym polityczny i ideologiczny wymiar unionizmu (Morrow 1995: 162163). Jedność społeczności protestanckiej opierała się na zaprzeczeniu, antykatolicyzmie - NIE jestem katolikiem.

Z drugiej strony, pomimo inicjatyw podejmowanych przez księży zarówno katolickich jak i protestanckich, mających na celu zbliżenie wyznawców, np. organizowane w kościołach spotkania, Kościoły pozostawały swoistymi bastionami "swojej” społeczności - nacjonalistów, republikanów w Kościele katolickim i unionistów w protestanckich. Poprzez swoją działalność, głoszone idee, a także poparcie dla określonych sił politycznych wyrażają, implicite lub explicite, pewność, że „Bóg jest po naszej stronie”.

„Nacjonalizm, zarówno irlandzki jak i brytyjski, zdaje się być religijny. Conor Cruise O’Brien mówił o nacjonalistycznej deifikacji Irlandii, o Ziemi Boga, Godland. lan Paisley nieustannie identyfikuje walkę ulsterskiego protestantyzmu jako walkę ludu wybranego przeciwko złu. Strajki głodowe więźniów w 1981 r. były explicite porównywane do ukrzyżowanego Chrystusa" (Morrow 1995: 166).

Poza religią zwolennicy interpretacji kulturowej zwracają uwage na odmienność sfer symbolicznych, do których odwołują się obie społeczności.

Protestanci podkreślają związek kulturowy i polityczny kraju z kulturą brytyjską. Symbole i rytuały, takie jak symbol Korony, rodzina królewska, flaga, święta narodowe, królewskie urodziny i śluby, stanowią istotną część życia publicznego. Historia Ulsteru jest łączona z historią Brytanii, a sam Zakon Orański jako ruch społeczny umiejscawiany jest w szerszym kontekście imperializmu i kolonializmu angielskiego (Ruane, Todd 1996: 181). Jednakże do sfery symbolicznej weszły także elementy celtyckiego dziedzictwa, jak The Red Hand of Ulster (Czerwona Ręka Ulsteru - symbol klanu O'Neillów; ale także nazwa jednej z bojówek lojalistów; w latach 1953-1972 jeden z elementów, symboli umieszcza- 
nych na oficjalnej fladze Ulsteru) czy postać Cu Chúlainna, epickiego bohatera, broniącego prowincji przed najazdem z południa wyspy. Zresztą obie strony, republikanie i lojaliści, odwołują się do tych samych celtyckich symboli - jak wspomniałam, dla lojalistów „red hand” jest symbolem oporu przez „najazdem” Irlandczyków, zaś dla republikanów walki z najazdem szkocko-brytyjskim. Podobnie interpretowana jest postać Cu Chúlainna dla republikanów jest symbolem walki z „brytyjskim” najeźdźcą, z kolei dla lojalistów jest symbolem walki i obrony przed „najazdem" z południa wyspy.

Trzeba jednak zauważyć, że ulsterscy protestanci utożsamiają się z kulturą brytyjską, traktując ją jako ważną podstawę grupowej tożsamości. Jednakże tym, co w największym stopniu ową tożsamość określa i kształtuje jest swoista grupowa interpretacja historii i kultury "regionu”. Stąd autoidentyfikacja i etnonimy: „Ulstermen” - Ulsterczycy czy „Ulsterness" - ulsterskość.

Innym przykładem może być stosowanie przez rządzących i polityków unionistycznych określeń „the Ulster people”, a nawet „the people" wyłącznie w odniesieniu do protestantów (Finlayson 1997: 81). Niektórzy z badaczy rozróżniają społeczności regionalnie i terytorialnie, np. odróżniając "Ulsterczyków" (Ulstermen) od "Irlandczyków" (Irishmen) lub wprowadzając element topograficzny do tego rozróżnienia (zwracający uwagę na nazwy małych wsi, ulic itp.) (McGarry, O'Leary 1995: 219, 230).

Symbolicznym wyrazem tożsamości i przynależności grupowej są murals. Są to malowidła na ścianach domów i budynków, umieszczane w miejscach publicznych. Obecnie jest ich około dwóch tysięcy. W zależności od tego, kto i w jakim miejscu je tworzył, prezentują dwie odrębne wizje przeszłości i tradycji oraz dwie różne interpretacje aktualnej sytuacji politycznej, ujmującej rzeczywistość w kategoriach nieustającej wojny. Wiele muralsów przedstawia treści paramilitarne: zamaskowanych żołnierzy, ofiary walki z wrogiem czy emblematy bojówek: IRA Provos, lojalistyczne Ulster Volunteer Force czy Ulster Defence Association. Równie popularne są malowidła przypominające o szczególnie doniosłych wydarzeniach historycznych, jak bitwa nad rzeką Boynne. W początkowym etapie konfliktu, nacjonaliści nie malowali murów (jako wyrazu sprzeciwu), jednak ta sytuacja uległa zmianie po 1981 r. i strajku głodowym (Rollson 1992).

Mniejszość katolicka, dając wyraz swej odrębności kulturowej, wykorzystywała (najczęściej w rysunkach sporządzanych na murach w swojej części miasta) motyw trójkolorowej flagi irlandzkiej - jest to o tyle ciekawe, że kolory zielony i pomarańczowy, symbolizujące katolików i protestantów, przedzielone są białym pasem, który miał oznaczać harmonię i pokój pomiędzy nimi. Poza symbolami IRA na murach pojawiły się także rysunki Irlandii w kobiecej postaci (częsty motyw w antyangielskiej poezji i literaturze), czy irlandzkich bohaterów narodowych związanych z powstaniem wielkanocnym, np. Jamesa Connolly'ego. Funkcję integrującą spełniają także symbole, przede wszystkim symbolskrót „IRA”, napisy po gaelicku - np. „Eire”, czyli „Irlandia”, przedstawienia celtyckich bohaterów, jak Cu Chúlainn, postaci bojowników IRA, którzy zginęli w walce itd. Z kolei protestanckie murale najczęściej przedstawiają Wilhelma Orańskiego bądź nawiązują do zwycięstwa nad Boynne. Częste są także malowidła przedstawiające emblematy bojówek protestanckich lub bohaterów - bojowników o wolność i niezależność Ulsteru (Rollson 1992).

Wilhelm Orański, a szczególnie bitwa nad Boynne (1691 r.) zajmują wyjątkowe miejsce w protestanckim uniwersum symbolicznym. Co roku w lipcu Zakon Orański organizuje marsze, upamiętniając zwycięstwo protestanckiego Wilhelma nad katolickim Jakubem. Trasa pochodu wytyczana jest przez katolickie dzielnice, co - tradycyjnie - prowadzi do 
rozruchów. Marsze są symbolicznym wyrazem politycznej, materialnej i kulturowej dominacji protestanckiej większości, symbolicznie uprawomocniają narzucony przez stronę dominującą ład społeczny. Rytualne marsze dostarczają protestantom nieustającego źródła i podstawy ich tożsamości, niezależnej od zajmowanej pozycji społecznej (Cairns 1998/9: 10). Opór ze strony mniejszości katolickiej jest wyrazem sprzeciwu wobec narzuconemu porządkowi politycznemu i społecznemu, odmową uznania i legitymizacji.

Bez wątpienia wraz z rozwojem procesu pokojowego zapoczątkowanego przez Porozumienie Wielkopiątkowe rosły oczekiwania i nadzieje mniejszości katolickiej, co do ograniczenia albo zupełnego zaprzestania marszów oranżystów. O tym, jak wielkie napięcie i emocje społeczne towarzyszyły i nadal towarzyszą tym demonstracjom siły, świadczyć mogą wydarzenia w Drumcree w 1996 roku. Przemarsz członków Zakonu Orańskiego przez katolicką dzielnicę doprowadził do ostrej reakcji mniejszości katolickiej, doszło do zamieszek i rozruchów. Niepokoje i napięcie w stosunkach pomiędzy obiema społecznościami rozlały się na resztę kraju. Sytuację udało się po jakimś czasie uspokoić, ale pokazata ona wyraźnie, jak silne są wzajemne animozje.

Range symbolu ma język irlandzki, gaelick, którego znajomość jest jednym z elementów samodefinicji katolika. Używanie go, szczególnie w miejscach publicznych, jest wyrazem przynależności do irlandzkiej, katolickiej wspólnoty, wyrazem sprzeciwu wobec dyskryminacji tej mniejszości. Z kolei protestanci posługują się językiem ulster-scots. Podstawową funkcję komunikacyjną spełnia jednak język angielski - i to na całej wyspie (np. McGarry, O'Leary 1995: 220-223).

Organizacje paramilitarne, takie jak IRA czy lojalistyczna Apprentice Boys of Derry, kreują wzorce osobowe wojowników walczących o słuszną sprawę, o wolność ojczyzny. Niektórzy badacze przywołują „teorię gwałtu w Irlandii Północnej”, która zakłada przyzwolenie i kult siły w obu społecznościach. Do jej elementów składowych zaliczyć można m.in. stereotyp „walczącego Irlandczyka” (the fighting Irish), nieufność wobec nowoczesnego państwa, która pozwala na istnienie kultury politycznej mającej tendencję do popierania pozapaństwowych działań siłowych, czy wreszcie tradycjonalistyczną patriarchalną socjalizację mężczyzny na żołnierza (McGarry, O'Leary 1995: 233).

W twórczości artystycznej tematyka związana z IRA, jej ideologią i walką, znalazła swój wyraz w wielu filmach, książkach, w poezji. Na poziomie społecznej rzeczywistości wyraża się w rytuałach (np. określony, powtarzalny sposób komunikowania o zbliżających się żołnierzach w dzielnicach katolickich), obyczajach (np. tworzenie "no-go areas" w dzielnicach katolickich i protestanckich, gdzie przedstawiciele wrogiej społeczności, policja i wojsko nie mają wstępu), w sferze symbolicznej, której przedstawienia można zobaczyć na murach stanowiących granice pomiędzy protestantami a katolikami, czy dostrzec w żonkilach, noszonych w Wielkanoc w butonierkach, jako wyraz pamięci o powstaniu wielkanocnym.

Irlandzka Armia Republikańska i narosły wokół niej mit jedynego obrońcy mniejszości katolickiej uprawomocnił zaistnienie wzoru osobowego młodego bojownika IRA, romantycznej wizji młodzieńca walczącego i umierającego za „sprawę”, wolną ojczyznę (McGarry, O'Leary 1995: 229-232). Ten heroiczny obraz przyciągał wielu młodych ludzi nie tylko z Ulsteru, ale i z Republiki Irlandii, którzy przybywali, by walczyć i ginąć za "sprawę". Równie często ci młodzi bojownicy dawali się złapać, by w nimbie świętości i męczeństwa spędzać lata w brytyjskich więzieniach (Olsson, Sjorgen 1974: 254-255). „Młodzież katolicka kontynuowała odgrywanie kluczowej roli w ulicznych konfrontacjach z policją oraz wojskiem i przyłączała się do IRA lub republikańskich sekcji młodzieżowych w znaczącej liczbie" (Bell 1990: 6). 
Elementem własnego wizerunku - jednostki lub grupy - jest także wizerunek antagonisty. Pomimo wielu inicjatyw pokojowych powstałych w obrębie obu społeczności, mających na celu wzajemne poznanie się i naukę tolerancji, nadal funkcjonują niezwykle silne stereotypy przedstawicieli obu grup. „Typowy” Irlandczyk to katolik, pijak, leń, nielojalny "Paddy" - od popularnego imienia Patryk (np. Ruane, Todd 1993: 182, 184). Z kolei "typowy" protestant to zadufany w sobie i w siłe brytyjskiego imperium „oranżysta" (członek Zakonu Orańskiego), nienawidzący katolików i obawiający się ich, człowiek, który nie potrafi wyjść poza narzucone mu schematy, zwolennik siłowych rozwiązań.

Podziału dokonuje się również ze względu na partycypowanie $w$ różnych systemach kulturowych - chodzi tu o mass-media, wolny czas, sporty, szkolnictwo, dziedzictwo językowe itd. Jest to koncepcja „paralelnych społeczeństw” (McGarry, O'Leary 1995: 220-227).

Wymienione powyżej sfery kultur etnicznych tworzą zróżnicowane uniwersum - począwszy od wzorców osobowych, poprzez style życia, wzorce zachowań politycznych, skończywszy na symbolach i znakach. Sądzę, że tworzą kulturowe ramy, w których jednostki indywidualnie kształtują swoją tożsamość etniczną - „irlandzką" lub „ulsterską".

W rozważaniach nad tożsamością, w tym także etniczną, powoływanie się na wzorce grupowe jest niewystarczające. Najważniejsze jest bowiem to, w jaki sposób i w jakim stopniu jednostki odnoszą się do owych wzorców, na ile i z którymi elementami się identyfikują i które z nich odgrywają kluczową rolę w indywidualnych procesach kształtowania tożsamości. Nie jestem w stanie ocenić, jak rozkładają się proporcje. Pomocne może być odwołanie się do koncepcji reakcji jednostki na "etniczność"; etniczność rozumiem tutaj szeroko, jako określoną płaszczyznę działań społecznych oraz warunkujących je symboli i znaków, a także wartości, kształtowaną przez grupę etniczną i uważaną za wyróżnik tej grupy spośród innych (nie jest to definicja, ale wyjaśnienie skrótu myślowego). Postawy wobec narzucającej się i narzucanej jednostce etniczności, co ma szczególnie doniosłe społecznie znaczenie w sytuacji konfliktu etnicznego, mogą przyjmować formę afirmacji etnicznej, ale także odrzucenia etniczności jako wyznacznika czy elementu konstytuującego tożsamość. Można mówić o continuum postaw zawartych pomiędzy dwoma biegunami, jakie mogą przyjmować poszczególne jednostki, ale także jakie może przyjmować jednostka w swej biografii. Możliwa jest także postawa samonienawiści (selfhatred), w której przynależność etniczna jest źródłem nienawiści, niechęci lub pogardy do samego siebie (por. Bokszański 2005; Babiński 1998).

Wśród republikanów czy lojalistów niewątpliwie pojawiają się rozmaite typy postaw etnicznych: IRA ciągle znajduje nowych, młodych członków pragnących walczyć w słusznej sprawie, z drugiej strony obserwuje się wysoki odsetek samobójstw wśród młodych ludzi w Ulsterze, co w pewnym stopniu wiąże się sytuacją konfliktu etnicznego.

Wymienione powyżej sfery czy obszary kultur obu grup etnicznych, układające się w ramy, symbolicznie służą nie tylko kształtowaniu tożsamości etnicznej, ale także budowaniu grupowej identyfikacji oraz grupowej integracji. Jednocześnie jest to proces - lub procesy - wytyczania granic grupy, granic pomiędzy swoimi a obcymi. Granice pomiędzy grupami etnicznymi to obszary szczególnie ważne, granice „wyobrażone”, tworzone przez samych członków, bazują na przekonaniu o niemożliwych (lub trudnych) do przekroczenia różnicach między "nami” a "nimi”. Zdaniem Fredrika Bartha to właśnie granica definiuje grupę etniczną, gdyż kontakt z obcymi pozwala na określenie swojej odrębności, wyrażającej się m.in. nazwaniem cech charakterystycznych i wyróżniających swojego od obcego (Barth 2004). 
Granice etniczne pomiędzy nacjonalistami, republikanami a lojalistami są zakreślone bardzo wyraźnie. Częściowo granice grupowe pokrywają się z granicami przestrzennymi, terytoriami obu społeczności (np. dzielnice miejskie protestanckie lub katolickie w miastach). Granice mają także charakter symboliczny, kulturowy i jednostka potwierdza swoje członkostwo w grupie poprzez uczestniczenie w określonych działaniach społecznych - np. kibicowanie tej a nie innej drużynie piłkarskiej, posługiwanie się w miejscach publicznych gealickiem, czy uczestniczeniem w paradzie 12 lipca.

Za przekroczenie granic lub ich lekceważenie groziły konsekwencje - „kary" wymierzane m.in. przez IRA wobec tych katolików, którzy sprzeciwiali się terrorowi fizycznemu i przemocy symbolicznej narzucanej przez bojówki, lub tych, którzy głosili idee współpracy ponad podziałami etnicznymi (por. koncepcje granic grupowych i członkostwa w grupie Stanisława Ossowskiego). Nierzadko karą za zdradę była śmierć.

\section{INICJATYWY POKOJOWE}

Zarysowane powyżej uwarunkowania społeczno-strukturalne i kulturowe tworzą ramy, w jakich rozgrywa się i postępuje proces pokojowy, a raczej poszczególne inicjatywy zmierzające do utrzymania i wzmocnienia pokoju w Irlandii Północnej. Wydaje się, że ogólnie można mówić o poparciu społecznym dla idei pokojowej koegzystencji obywateli, świadczyć o tym może wynik referendum (choć trzeba zauważyć, że społeczność katolicka w większym stopniu skłonna jest popierać te ideę). Jednakże na poziomie poszczególnych społeczności, aktorów społecznych takich jak grupy polityczne czy ideologiczne, społeczności lokalne, owo poparcie może przyjmować różny stopień, ale i różną formę im bardziej polityka „wspólnej przyszłości” uderza w interesy np. bojówek czy organizacji paramilitarnych, ale także w układy lokalnych powiązań, tym mniejsza jest zgoda członków na rezygnację z przywilejów i pozycji.

Bez wątpienia ważną rolę w procesie pokojowym pełni Zgromadzenie Północnoirlandzkie oraz administracja rządowa, kreująca polityczne warunki do promowania i podejmowania konkretnych działań, programów mających na celu wprowadzanie koniecznych zmian nie tylko politycznych i ustawodawczych, ale także instytucjonalnych, służących poprawie warunków życia mniejszości katolickiej oraz wypracowywaniu wspólnych strategii rozwojowych, gospodarczych czy społecznych. Nadrzędnym dokumentem definiującym strategię władz północnoirlandzkich jest dokument o kluczowym znaczeniu, przygotowany przez rząd i opublikowany w marcu 2005 r., zatytułowany A Shared Future - Policy and Strategic Framework for Good Relations in Northern Ireland. Deklaracja ta podkreśla wolę i wagę, jaką do budowania poprawnych relacji pomiędzy obiema społecznościami przywiązują nowe władze północnoirlandzkie; celem jest zbudowanie obywatelskiego shared society. Poszczególne ministerstwa oraz organy administracji rządowej przyjęły szereg programów służących poprawie relacji dotyczących różnych sfer współdziałania społecznego, m.in. program rządowy na lata 2008-2011 (The Executive's Programme for Government), powstanie nowych sit policyjnych - Police Service of Northern Ireland oraz zainicjowany w 2000 r. przez władze w Westminsterze program odnowy i pomocy dla najbiedniejszych społeczności lokalnych (Neighbourhood Renewah).

Interesujące jest to, jak społeczności lokalne odbierają rządowe i pozarządowe inicjatywy i programy, mające na celu zarówno naprawę sąsiedzkich stosunków jak i poprawę 
materialnych warunków życia. Do pewnego stopnia wyniki takich lokalnych programów obrazują rzeczywiste porozumienia lub chęć porozumienia czy współpracę aktorów społecznych. Uczestnictwo w takim programie, lub jego odmowa, może być probierzem podziałów etnicznych, może pośrednio ukazywać formę i stopień otwartości wobec samego procesu pokojowego jak i "sąsiadów": nie tylko katolików czy protestantów, ale także przedstawicieli mniejszości etnicznych i narodowych zamieszkujących Irlandię Północną.

Jednym z programów zainicjowanych i finansowanych przez kilka instytucji rządowych jest, a raczej był, Re-imagining Communities Programme, realizowany pod egidą Arts Council of Northern Ireland (por. Evaluation of the Re-imagining Communities Programme: A Report to the Arts Council of Northern Ireland Independent Research Sollutions, 2009). Celem programu była zmiana lokalnego obrazu grupy, a raczej lokalnego wyrazu grupowych tożsamości i identyfikacji, wyrażana symbolicznie na murach (murals), oznakach, w postaci obrazów, malunków. Animatorzy programu starali się zachęcać lokalne społeczności, między innymi w drodze negocjacji społecznych z mieszkańcami oraz współpracą z lokalnymi władzami, do wyrażania grupowej tożsamości w odmienny niż do tej pory, pokojowy, nieagresywny sposób, odwołujący się do symboli grupowych, które mieszkańcom nie kojarzą się jednoznacznie z walką czy przemocą.

Program rozpoczął się w 2006 r. i trwał około 3 lat. Zgłoszono 177 projektów, z czego 123 zostały otrzymały granty. Budżet programu łącznie wyniósł ponad 3 mln funtów. Program był skierowany przede wszystkim do społeczności lokalnych dotkniętych deprywacją. Z jednej strony celem było usuwanie z publicznej przestrzeni obrazów propagujących uprzedzenia sekciarskie lub rasistowskie i zamienianie ich na obrazy o treści "pozytywnej, włączającej i nieodstraszającej". Z drugiej - renowacja, rewitalizacja wizerunku miejsca, poprzez sprzątanie i czyszczenie publicznej przestrzeni, sadzenie drzew i krzewów, a także montowanie instalacji artystycznych.

Ważnym elementem programu były konsultacje społeczne, rozmowy z lokalnymi władzami oraz mieszkańcami terenów objętych programem, a także lokalnymi artystami, wykonawcami nowych malowideł lub instalacji, długotrwałe i wielostopniowe spotkania i wywiady, w trakcie których wspólnie uzgadniano treść i formę, a także symbole umieszczane na nowych muralach. Interesujące jest, że animatorom programu udało się zaangażować te grupy, które w dotychczasowym dyskursie ideologicznym zajmowały marginalne pozycje - dzieci i młodzież oraz kobiety. W ten sposób nowe murale stały się symbolicznym środkiem wyrazu i zarazem komunikatem wysyłanym przez grupy dotychczas zmarginalizowane i pozbawione prawa głosu w sprawach uznanych za "sprawy wojenne".

W wielu przypadkach, podczas etapu negocjowania nowych wizerunków społeczności lokalnych, okazywało się, że porozumienie pomiędzy poszczególnymi aktorami społecznymi jest niemożliwe. Wielu liderów społeczności twierdziło, że nie ma - jeszcze? - szans na współpracę z „drugą stroną". Podziały narosłe w trakcie kilkudziesięciu lat konfliktu są bez wątpienia silne, a negatywne emocje głębokie.

W ocenie twórców i animatorów programu zmiana militarnych lub sekciarskich treści jest sposobem na neutralizację i wygaszanie tychże emocji, czynieniem danego obszaru czy terenu bardziej neutralnym symbolicznie i aksjologicznie, a dzięki temu lepszym i spokojniejszym miejscem do życia. A to może być pierwszym krokiem do budowania porozumienia.

Swoistym komentarzem do samego projektu Re-imaging Communities, ale także do powyższej oceny wyników programu, jest artykut, dziennikarski reportaż Symbols of the Peace, opublikowany w tygodniku "The Big Issue of the North" (Briggs 2010). Artykut 
poświęcony jest ocenie programu, z perspektywy jego uczestników i społeczności lokalnych. Także w tej publikacji prezentowane są pozytywne opinie o programie, a także o samym fakcie zamiany symbolicznych malowideł na murach budynków, o treściach sekciarskich na bardziej neutralne. Zdaniem przywoływanych w artykule działaczy społecznych znacząco i pozytywnie wspierają proces pokojowy. Świadczyć może o tym, pośrednio, zainteresowanie i chęć udziału w programie wielu społeczności lokalnych.

Interesujące w przywoływanym artykule są dwie sprawy. Po pierwsze, w ocenie działaczy, w efekcie kolejnych działań podejmowanych w ramach procesu pokojowego, atmosfera i relacje pomiędzy obiema antagonistycznymi społecznościami, a szczególnie pomiędzy lojalistami a nacjonalistami, się poprawiły. Jednakże nadal zdarzają się morderstwa i zabójstwa dokonywane przez członków bojówek. Dochodzi do nich, jak i do aktów agresji, znacznie rzadziej. Ponadto są one zdecydowanie potępiane przez społeczność lokalną (np. zastrzelenie w maju 2010 r. na ulicy Bobby'ego Moffeta, przez zamaskowanego członka Red Hand Commando. Pomimo groźby ze strony Ulster Volunteer Force skierowanej do osób chcących uczestniczyć w pogrzebie, wzięło w nim udział blisko dwa tysiące ludzi).

Po drugie, zmiana treści murali, malowanie na ich miejscu nowych lub częściowa zmiana już istniejących wiąże się także z tworzeniem nowej symbolicznej wizytówki miejsca, a także wizytówki żyjących tam ludzi. W dużym stopniu murale są wyrazem i znakiem tożsamości grupowej i etnicznej. Czy zmiana znaku pociąga za sobą zmianę, przedefiniowanie tożsamości grupy? Jeśli tak, to w jakim stopniu? Ponieważ, zgodnie z założeniami programu, zmiany lub nowe murals muszą być wspólnie uzgodnione przez przedstawicieli lokalnych władz oraz członków lokalnej społeczności, wydaje się, że zgoda na konkretną propozycję, wybór takich a nie innych „nowych” treści mających symbolizować grupę, może wiązać się z próbą wypracowania nowej albo nowej-starej tożsamości.

Interesująca w powyższym kontekście jest osoba jednego z bohaterów artykułu, Davida Stitta, byłego członka Ulster Defence Association, aktywnego „bojownika” z wrogami Ulsteru, który za swoją działalność oraz posiadanie broni spędził wiele lat w więzieniu. Obecnie jest jednym z działaczy organizacji działających na rzecz pokoju: Charter for Northern Ireland i Belfast Conflict Resolution Consortium. Stitt nie żałuje ani nie próbuje się odciąć od swojej bojówkarskiej działalności, uważa, że była potrzebna. Nie zmienił poglądów, ale chce w inny, pokojowy sposób zapewnić swojej rodzinie spokojne życie.

Odbiciem takiej postawy są nowe murale - nie oznaczają zerwania z przeszłością ani jej potępienia, ale raczej rezygnację z treści o militarnym charakterze. Owe złagodzone w wymowie malowidła nadal mają podkreślić odrębność kulturową. W przypadku lojalistycznych malowideł we wschodnim Belfaście, nowe murale podkreślają ważny element tożsamości grupowej, a mianowicie - tak czy inaczej rozumianą - "brytyjskość"; jak pisze Briggs, „they wanted to move away form militaristic murals but also retain their British identities" (2010: 17).

\section{ZAKOŃCZENIE}

Analizując społeczno-strukturalne oraz kulturowe uwarunkowania i jednocześnie ograniczenia procesu pokojowego, można wyróżnić przeszkody natury zewnętrznej, systemowej i w tym sensie obiektywne. Należą do nich różne obszary dyskryminacji, prezentowane w artykule - począwszy od ustawodawczego na socjalnym skończywszy. 
$\mathrm{Na}$ tym poziomie rzeczywistości społecznej zmiany mające na celu zniwelowanie lub zniesienie dyskryminacji, to gtównie zmiany inicjowane i przeprowadzane przez obecnie rządzące władze, będące wynikiem i efektem negocjacji politycznych (najważniejsze to Good Friday Agreement, St. Andrews Agreement, Hillsborough Castle Agreement). Nowy parlament Northern Irish Assembly to nie tylko zmiana na poziomie semantycznym i symbolicznym, ale także dopuszczenie do realnej władzy przedstawicieli mniejszości katolickiej, wybranych w demokratycznych wyborach. W wyborach parlamentarnych w 2007 r. pierwsze miejsce z 30\% poparciem uzyskała Democratic Unionist Party, jednakże na drugim miejscu, z wynikiem około $26 \%$ poparcia, uplasowała się Sinn Feinn. Kolejne miejsca zajęły SDLP (partia nacjonalistyczna), Ulster Unionist oraz Alliance. W 2011 r. w majowych wyborach parlamentarnych wyniki kształtowały się podobnie, największą liczbę głosów oraz miejsc w NI Assembly uzyskały DUP (38 mandatów) i Sinn Feinn (29 mandatów), następnie kolejno UUP - 16 i SDLP - 14 (przy niskiej frekwencji wyborczej).

Po raz pierwszy od powstania Irlandii Północnej mniejszość katolicka, poprzez swoich demokratycznie wybranych reprezentantów, zyskała wpływ na realną władzę na poziomie polityki wewnętrznej. Znaczący w tym kontekście jest sukces wyborczy i polityczny Sinn Feinn, która z marginalnej partii republikańskiej przekształciła się w znaczącego gracza politycznego; ostatnie wybory parlamentarne w Republice Irlandii pokazały także znaczący wpływ i poparcie dla tego ugrupowania.

Polityka dewolucji (,devolution of policing and justice to Belfast") doprowadziła do utworzenia nowego rządu, w którym teki ministerialne otrzymali przedstawiciele nacjonalistycznych partii katolickich, a stanowisko Deputy First Minister objął zastępca Gerry'ego Adamsa, Martin McGuinness (po majowych wyborach został ponownie wybrany na to stanowisko). Realną zmianą jest także rozwiązanie sił policyjnych RUC i zastąpienie ich przez Northern Ireland Policing Service, w których udział mają także policjanci wywodzący się z mniejszości katolickiej. Zmiany na poziomie instytucji rządowych oraz tworzonego przez nie prawa, także w zakresie polityki społecznej, są ważne i eliminują wiele spośród czynników, które przyczyniały się do zaogniania konfliktu. Można je potraktować jako poważną próbę przekształcenia i przedefiniowania starego porządku społecznego, w stronę takiego ładu społecznego, który będzie oparty na pokojowej, wspólnej koegzystencji (idea i polityka shared future).

Z drugiej strony istotne znacznie mają zmiany - postulowane i te przeprowadzane wewnętrzne, subiektywne zmiany na poziomie kulturowym, ale także jednostkowym, czyli percepcji i ewentualnej akceptacji „nowego ładu”. Z przywołanych wcześniej badań i analiz wynika, że obie społeczności - katolicy i protestanci - identyfikują się z odmiennymi kulturami, jednoznacznie określanymi w kontekście etniczno-narodowym, a więc z kulturą irlandzką i brytyjską, z irlandzkością i brytyjskością. Oznacza to odwoływanie się do innych symboli, wzorców osobowych i wzorów zachowań. W tym przypadku instytucjonalne zadekretowanie zmiany jest niemożliwe. O wadze i trwałości więzów i identyfikacji kulturowej świadczyć mogą wydarzenia z Drumcree, a także fakt, że polityczne negocjacje dotyczące parad oranżystów, m.in. zmiany tras, prowadzone były na wysokim szczeblu.

Sądzę, że proces pokojowy, rozumiany jako rezygnacja z walki zbrojnej, nie musi oznaczać rezygnacji z tradycyjnej tożsamości. Wydaje się jednak, że koniecznym warunkiem trwania procesu pokojowego jest redefinicja dotychczasowych etnicznych tożsamości grupowych; redefinicja tych elementów, wzorców i wartości, które bezpośrednio gloryfikowały "wojnę" i ponoszone w efekcie ofiary - śmierć poległych bojowników lub wyrok 
więzienia z powodów politycznych (w przypadku nacjonalistów w więzieniu Maze, w którym głodówkę prowadził Bobby Sands). Inicjatywa leży po stronie liderów politycznych - zarówno partii republikańskich, jak i unionistycznych - kreujących na poziomie administracyjnym i symbolicznym (nowe nazwy, nowe instytucje, nowa polityka państwa) nowy porządek społeczny.

Wsparcie ze strony instytucji rządowych może ułatwić inicjatywy pokojowe na poziomie lokalnych społeczności, ale zmiana postaw obu tak głęboko i na wielu płaszczyznach skonfliktowanych stron niewątpliwie potrwa bardzo długo. Nie wszyscy też są zwolennikami nowego ładu społecznego, i dla nich walka zbrojna wcale się nie skończyła, o czym mogą świadczyć zabójstwa i ataki terrorystyczne dokonywane przez członków bojówek. Dla wielu nowa ideologia: zamiast walki negocjacje i zgoda na konieczne ustępstwa - to zdrada. Zdrada zarówno ideałów, jak i moralna zdrada tych, którzy ponieśli śmierć „za sprawę".

\section{BIBLIOGRAFIA}

Altermatt Urs. 1998. Sarajewo przestrzega. Etnonacjonalizm w Europie, Wydawnictwo Znak, Kraków.

Babiński Grzegorz. 1998. Etniczność, w: Encyklopedia socjologii, W. Kwaśniewicz (red.), t. 1, Oficyna Naukowa, Warszawa.

Barth Fredrik. 2004. Grupy i granice etniczne: społeczna organizacja różnic kulturowych, w: E. Nowicka, M. Kempny (red.), Badanie kultury Elementy teorii antropologicznej, Wydawnictwo Naukowe PWN, Warszawa.

Bell, Desmond. 1990. Acts of Union: Youth and Sectarian Culture in Northern Ireland, London, Macmillan Press.

Bokszański Zbigniew. 2005. Tożsamości zbiorowe, Wydawnictwo Naukowe PWN, Warszawa.

Briggs Billy. 2010. Symbols of the Peace, "The Big Issue in the North”, nr 836, 9-15 August 2010, s. 16-18.

Cairns David. 1998/9. A March Past? Orangeism, Sectarianism, Discourse, Power. Niepublikowany tekst, pochodzący z 1998 lub 1999 r., otrzymany dzięki uprzejmości Jima Smytha z Queens University w Belfaście.

Dixon Paul. 2001. Northern Ireland The Politics of War and Peace, Houndmills, New York; Palgrave.

Finlayson Alan. 1997. Discourse and Contemporary Loyalist Identity, w: Mark McGovern, Peter Shirlow (eds), Who Are the People?, London, Pluto Press.

Glazer Nathan, Daniel Moynihan. 1975. Ethnicity: Theory and Experience, Cambridge Mass: Harval Univ. Press.

Gruszka Witold. 1977. Konflikt w Irlandii Północnej, Warszawa, MON.

Gruszka Witold. 1986. „Szmaragdy” nie lubią koloru khaki, Warszawa, KAW.

Hillyard Paddy. 1983. Law and Order, w: John Darby (ed.) Northern Ireland. The Background of the Conflict, Belfast, Appletree Press.

Isajiw Vsevolod. 1974. Definitions of Ethnicity, „Ethnicity” 1, s. 111-124.

Konarski Wawrzyniec. 1991. Nieprzejednani. Rzecz o Irlandzkiej Armii Republikańskiej, Warszawa, TOR. 
Kubiak Hieronim. 1980. Asymilacja etniczna w płaszczyźnie struktury społecznej, w: Hieronim Kubiak, Andrzej K. Paluch (red.), Założenia teorii asymilacji, Wrocław, Ossolineum, s. 55-56.

Kula Marcin. 1988. Irlandzka wizja ojczyzny. Część I, „Przegląd Polonijny”, XIV, z. 4, s. 25-52.

Kula Marcin. 1989. Irlandzka wizja ojczyzny. Część II, „Przegląd Polonijny”, XV, z. 1, s. 19-42.

Mach Zdzisław. 1989. Symbols, Conflict and Identity, Kraków, Nakładem Uniwersytetu Jagiellońskiego.

McGarry J., B. O'Leary. 1995. Explaining Northern Ireland, Oxford, Blackwell.

Morrow Duncan. 1995. Church and Religion in the Ulster Crisis, w: Seamus Dunn (ed.) Facets of the Conflict in Northern Ireland, St. Martin's Press.

Mucha Janusz. 1980. Przeobrażenia społeczeństwa wieloetnicznego pod wpływem konfliktów etnicznych, w: Hieronim Kubiak, Andrzej K. Paluch (red.), Założenia teorii asymilacji, Ossolineum, Wrocław, s. 127-146.

Nowicka Ewa. 1980. Przyczynek do teorii etnicznych mniejszości, w: Hieronim Kubiak, Andrzej K. Paluch (red.), Założenia teorii asymilacji, Ossolineum, Wrocław, s. 105-126.

O'Day Alan. 1997. Political Violence and Conflict Resolution in Northern Ireland, w: Alan O'Day, (ed.), Political Violence in Northern Ireland. Conflict and Conflict Resolution, Westport-Connecticut-London, Praeger, s. 1-12.

Olsson Jan Olof, Margareta Sjorgen. 1974. Niż nad Irlandią, Warszawa, Iskry.

Posern-Zieliński, Aleksander (red.). 2003. Etniczność a religia. Wydawnictwo Poznańskie. Poznań.

Rollson Bill. 1992. Drawing Support: Murals in the North of Ireland: http://cain.ulst.ac.uk/ bibdbs/murals/rolston1.htm

Rowthorn Bob, Naomi Wayne. 1988. Northern Ireland. The Political Economy of Conflict, Cambridge, Polity Press.

Ruane Joseph, Jennifer Todd. 1993. 'Why can't you get along with each other?': culture, structure and the Northern Ireland conflict, w: Eamonn Hughes (ed.), Culture and Politics in Northern Ireland 1960-1990, Philadelphia, Open University Press, Milton Keynes, s. 27-40.

Sadowski Andrzej. 1973. Pojęcie grupy etnicznej w socjologii, „Studia Socjologiczne”, nr 4, s. 173-190.

Sands Bobby. 1990. Jeden dzień w moim życiu, tł. Piotr Stalmaszczyk, Warszawa, Wydawnictwo Przedświt.

SOCIAL AND CULTURAL CONDITIONS AND LIMITATIONS OF THE NORTHERN IRELAND'S PEACE PROCESS

\section{Summary}

The conflict in Northern Ireland, sometimes called "The Troubles" (by British government), sometimes called "war" (by nationalists), has lasted since 1921. The article presents historical, structural and cultural background of Ulster's conflict. Two main communities - catholic and protestant - are divided because of lots of reasons: one of them is different interpretation of history ("imagined histories"). On the social level the dominant position of the protestant community was supported by a system of discrimination. Two conflicted communities are integrated around different sets of val- 
- EWA SZCZECIŃSKA-MUSIELAK

ues, symbols, norms. Feeling of belonging and group membership is connected with different ethnic identities.

The peace process started in 1998 (Good Friday Agreement). Since then lots of changes have been put into execution in order to end political, social and cultural discrimination of the minority catholic community. Changes (reforms) at governmental level, like establishing new Northern Ireland Assembly or Northern Ireland Police Service, are very important. But equally important are changes on cultural and symbolic levels because they create space to re-defining ethnic identities. A good example of this could be The Re-imaging Community Programme, an initiative launched in 2006 by the Arts Council of Northern Ireland. The idea of the programme is to change - in cooperation with local people and artists - sectarian and fighting murals into neutral and create more friendly public space.

Keywords: Ulster's conflict, loyalists, nationalists, discrimination, "Britishness" and "Irishness", murals 